\title{
Development of novel nanomaterials for remediation of heavy metals and radionuclides in contaminated water
}

\author{
Kai Guo ${ }^{1} \cdot$ Fengxiang X. Han ${ }^{1} \cdot$ William Kingery ${ }^{2} \cdot$ Hua Sun $^{3} \cdot$ Jiuquan Zhang $^{4}$
}

Received: 2 August 2016/Accepted: 13 September 2016/Published online: 22 September 2016

(C) Springer International Publishing Switzerland 2016

\begin{abstract}
The contamination of toxic heavy metals and radionuclides has become a serious health and political issue. Since the outrage of several nuclear power plant accidents led to contamination in water and the surrounding areas, these heavy metals and radionuclides deteriorate the hydrosphere and the anthroposphere. This critical review discussed the state-of-the-art development of novel nanomaterials to meet the urgent needs for remediation of contaminated water with most noxious heavy metals and radionuclides. Nanocarbon, mesoporous materials and magnetic materials demonstrate their exceptional efficiency in cleaning up various metals under real environmental conditions. In this review, nanomaterials are elucidated from mechanisms, characterization, and synthetic methods. Magnetic mesoporous carbon composites have a high potential in the adsorption of heavy metals. Self-assembly strategy has become the most frequent method of synthesizing sorbents. The advanced instrumentation including SEM, HRTEM, XPS, XANES, TPD has been employed for comprehensive characterization of these novel materials. The exploration of adsorption mechanisms has showed that ion exchange and surface complexation with AFM, 2D FTIR, etc., were main
\end{abstract}

Fengxiang X. Han

Fengxiang.han@jsums.edu

1 Department of Chemistry and Biochemistry, Jackson State University, Jackson, MS, USA

2 Department of Plant and Soil Science, Mississippi State University, Starkville, MS, USA

3 Department of Resource Environment and Urban-Rural Planning Management, Nanjing Agricultural University, Nanjing, China

4 Chinese Academy of Agricultural Sciences, Qingdao, China mechanisms for adsorption of these metals, implying significant potentials in remediation of these hazardous metals.

Keywords Heavy metal $\cdot$ Nanocarbon $\cdot$ Mesoporous · Magnetic $\cdot$ Instrumentation $\cdot$ Mechanism

\section{Introduction}

Heavy metals have been significantly released into the environment [1, 42]. A significant amount of heavy metals are generated from the annual mining of their respective ores $[40,43,44]$. Besides, industrial waste and vehicle emissions, lead-acid batteries, paints, treated woods, and aging water supply infrastructures are other important sources [45]. The toxic effects of heavy metals have been well documented (Table 1). Some of these trace metals, $\mathrm{Zn}, \mathrm{Cu}$, etc., are prone to affect vital cellular components, such as structural proteins and nucleic acids, while others cause the enzyme dysfunction [55]. For some metals such as mercury $(\mathrm{Hg})$, the maximum contaminant level (MCL) is extremely low $(0.03 \mu \mathrm{g} / \mathrm{L})$ since $\mathrm{Hg}$ can lead to rheumatoid arthritis and diseases of kidneys, as well as circulatory and nervous systems [12]. Lead $(\mathrm{Pb})$ is linked to damage of the fetal brain and diseases of kidneys, circulatory systems, and the nervous system [11]. USEPA has not set a safety limit for $\mathrm{Pb}$ [31]. In 2016, Flint, Michigan, became a major news event because of $\mathrm{Pb}$ contamination from the corroded water pipes [35, 56]. Residents had been drinking $\mathrm{Pb}$-contaminated water for months, which was a threat to children and infant health and triggered political repercussions [16].

Worldwide expansion of nuclear energy raises the risk of radiation exposure [18]. In 2011, the Fukushima Daiichi 
Table 1 Brief summary on health effects of most noxious metals and radionuclides

\begin{tabular}{|c|c|c|}
\hline $\begin{array}{l}\text { Heavy } \\
\text { metals }\end{array}$ & Health effects & Incidents \\
\hline $\mathrm{Hg}$ & $\begin{array}{l}\text { Rheumatoid arthritis and diseases of kidney, circulatory } \\
\text { systems, and nervous system }\end{array}$ & \\
\hline $\mathrm{Pb}$ & $\begin{array}{l}\text { Damage of the fetal brain and diseases of kidney, circulatory } \\
\text { systems, and nervous system, bioavailability in crops in } \\
\text { acidic soil }\end{array}$ & $\begin{array}{l}\text { Washington D.C. lead contamination, } 20 \text { times of action level [67]; } \\
\text { New Orleans urban soil contamination, } 500-1000 \mathrm{mg} / \mathrm{L} \text { [90]; Flin } \\
\text { water crisis, lead level up to } 13,200 \mu \mathrm{g} / \mathrm{L} \text { [56] }\end{array}$ \\
\hline $\mathrm{Cd}$ & Bioavailability in crops, i.e., rice, growing in acidic soil & $\begin{array}{l}\text { Xiangjiang River, China, poison level reached } 4.6 \mu \mathrm{g} \text { per kg body } \\
\text { weight [2] }\end{array}$ \\
\hline${ }^{90} \mathrm{Sr}$ & Hypocalcemia, assimilation to plants & Three Mile Island, Chernobyl, and Fukushima \\
\hline${ }^{137} \mathrm{Cs}$ & Long half-life (137a) brings long-term radioactivity effects & \\
\hline${ }^{60} \mathrm{Co}$ & Gamma emitter and long half-life (5.27 a), contact dermatitis & Mistakenly disassembled to Juarez, Mexico, in 1984 \\
\hline
\end{tabular}

nuclear power plant was inundated up to $15 \mathrm{~m}$ due to the earthquake and tsunami, which brought a huge release of ${ }^{90} \mathrm{Sr},{ }^{137} \mathrm{Cs},{ }^{235} \mathrm{U}$, and ${ }^{129} \mathrm{I}$ into the sea water. These fission products may ultimately enter the food chain, posing a threat to humans [88]. Also wildlife modeling indicates that depleted uranium primarily affects assimilation [50]. ${ }^{137} \mathrm{Cs}$ is a beta-gamma emitter with a long half-life of 30 years [28]. Experiments with dogs showed that a single dose of 3.8 millicuries ${ }^{137} \mathrm{Cs}$ per kilogram was lethal within 3 weeks. Smaller amounts may cause infertility and cancer [74]. ${ }^{137}$ Cs can easily enter into human body and persist a long time. As a result, tissues are irradiated, leading to serious diseases such as cancer and leukemia [4, 24, 70].

${ }^{90} \mathrm{Sr}$ is a beta emitter with a half-life of 29 years and easily persists in environment [28, 75, 82]. Besides, the potential beta energy of ${ }^{90} \mathrm{Sr}$ (end point energy $0.54 \mathrm{MeV}$ ) and its daughter nuclide ${ }^{90} \mathrm{Y}(2.27 \mathrm{MeV})$ is high [82]. Strontium (Sr) delivers long-term beta radiation in skeletal and surrounding tissues, and high doses cause hypocalcemia due to increased renal excretion of $\mathrm{Ca}[64,77,82]$. Sr became a serious issue with the accidental release from Chernobyl (to the atmosphere) and Fukushima (to seawater) [91]. The post-Chernobyl study of ${ }^{90} \mathrm{Sr}$ pools contributing to the Black Sea budget showed that the river-derived share of ${ }^{90} \mathrm{Sr}$ input up to $25 \%$ of the total input during the first 10 years after the accident, which continued to grow [53]. Strontium accumulation in leaf tissue damaged various processes in photosynthesis, such as energy absorption, energy transfer, and photosynthetic carbon assimilation [19]. ${ }^{60} \mathrm{Co}\left(\mathrm{t}_{1 / 2} 5.3 \mathrm{y}\right)$, a strong gamma-ray source, is readily traced by its high activity [6, 39, 69]. Nuclear weapons incorporate ${ }^{59} \mathrm{Co}$, which is dispersed as ${ }^{60} \mathrm{Co}$ in fallout, forming a cobalt bomb [51]. Cobalt was a serious hazard following the inappropriate disposal of radioactive machine parts containing ${ }^{60} \mathrm{Co}$ after a radiotherapy unit was mistakenly disassembled in Juarez, Mexico, in 1984. Chronic ingestion of $\mathrm{Co}$ caused severe health problems even at amounts far less than the lethal dose [17]. Co is the major cause of contact dermatitis [15].

With increases in release of these toxic and radionuclides and heavy metals, the remediation of contaminated waters requires cost-effective materials. In this review, current strategies in the use of nanomaterials for the treatment of heavy metals and radionuclides are presented. Three types of nanomaterials, namely nanocarbon, mesoporous material, and magnetic materials, will be highlighted. In addition to synthesis and characterization, remediation mechanisms will be elucidated as well. Since all radionuclides possess exact same physical-chemical properties as their stable isotopes, they behave similarly in terms of environmental fates as their stable isotope in the environment and ecosystems except high ecotoxicity to living organisms. Thus, the mechanisms to remediate radionuclides are the same with their stable isotopes.

\section{Development of nanocarbons}

\section{Synthesis}

Synthetic processes, which involve the hybridization of carbon yielding a high degree of stability, i.e., the change in electron structure from $\mathrm{sp}^{3}$ to $\mathrm{sp}^{2}+\pi$, controlled the morphology of nanomaterials for removal of heavy metals. Among many synthetic routes, self-assembly is the core process which reduces many steps, but achieves the customized features of materials. Besides, clean ways for the synthesis are on the trend. Since graphene oxide (GO) displayed good dispersal property, much attention was paid to grafting various substances on it. Ag NP confirmed the synergistic effect with GO. Besides, a green method for the synthesis of this composite was proposed, which brought profits for the sustainable environmental research [87]. Dry plasma was induced, which contained majorly $\mathrm{H}^{+}, \mathrm{H}^{-}$and 
Fig. 1 The SEM images illustrate the evolution of the flower-like hierarchical GO/ HAp composite. At the beginning, only $\mathrm{Ca}^{2+}$ bound to $\mathrm{GO}$, and at the last stage, HAp became flower-like structure. This was a typical example about how biomimetic technique could be applied to synthesize various-shape nanoparticles (Modified from [88] (Copyright from Royal Society of Chemistry))
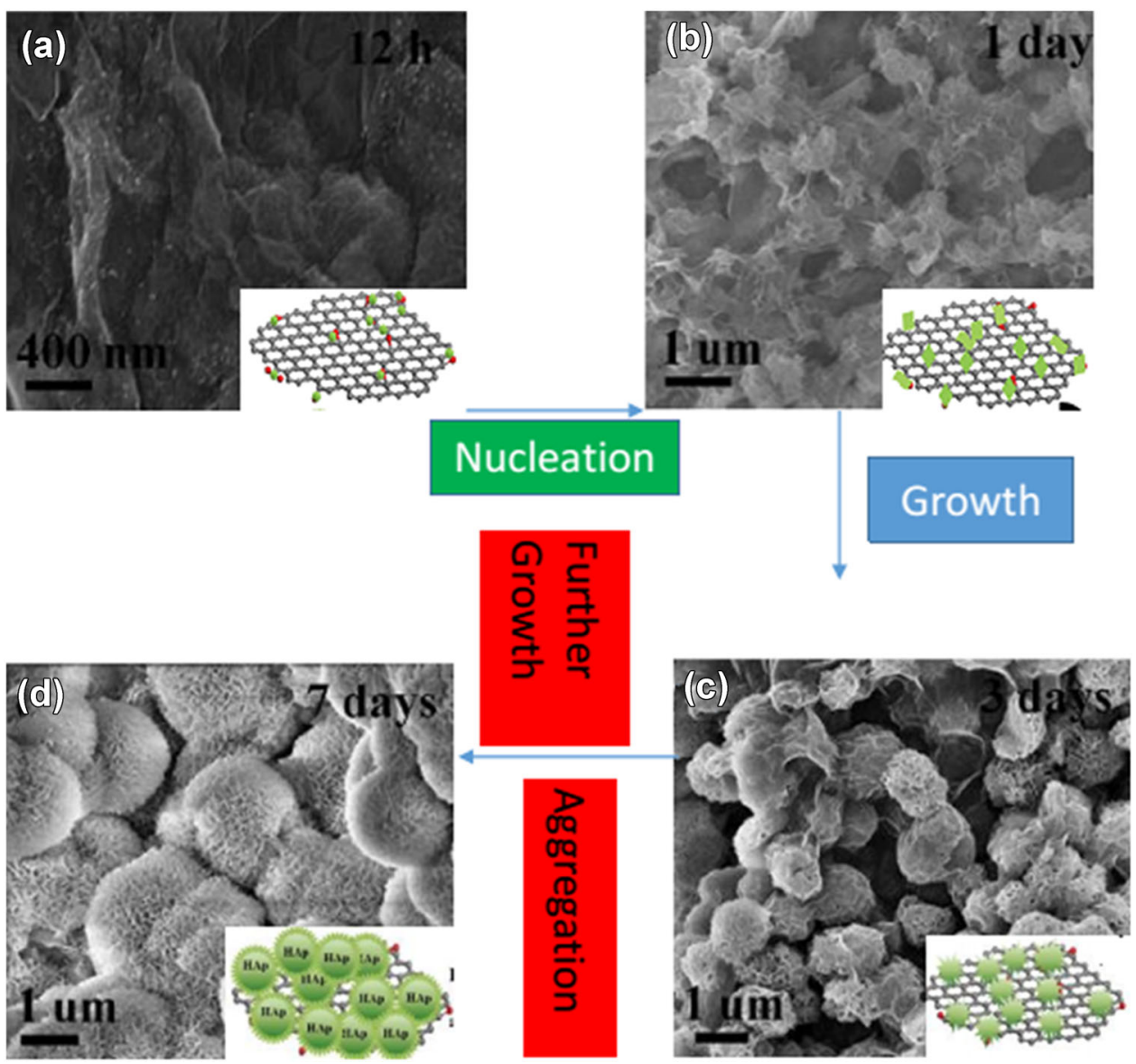

electron, good sources to reduce Ag to metallic state [49]. In addition, dry plasma with low energy would not cause the evaporation of $\mathrm{Ag}$. In some cases, GO/polypyrrole (GO/PPy) composite was synthesized from dielectric barrier discharge (DBD) plasma in $\mathrm{N}_{2}$. The charge density of pyrrolic nitrogen was increased due to GO.

Not only GO but also polymer-based sorbents are on the route of rapid development of green synthetic strategy. Glutaraldehyde and epichlorohydrin are two common cross-linkers in polymers, whereas the high levels of immunogenicity, carcinogenicity, and toxicity to humans and animals made them less viable [46, 93]. Ethylenediaminetetraacetic acid (EDTA) and diethylenetriaminepentaacetic acid (DTPA) were employed as the cross-linker to synthesize magnetic chitosan nanocomposite from the reversed-phase water/oil emulsion crosslinking method [96]. Another advantage of this material was that both magnetic EDTA and DTPA chitosan sorbents (MEDCS and MDTCS) were optimized at $\mathrm{pH}$ 2, as $\mathrm{H}_{3} \mathrm{EDTA}^{-}(55 \%)$ and $\mathrm{H}_{4} \mathrm{DTPA}^{-}(54 \%)$ in such low $\mathrm{pH}$, which were subjected to the electrostatic attraction with heavy metal cations. The selectivity of MEDCS was found to be $\mathrm{Ni}$ (II) $>\mathrm{Pb}$ (II) $>\mathrm{Cd}$ (II)
$>\mathrm{Co}$ (II) and that of MDTCS was $\mathrm{Pb}(\mathrm{II})>\mathrm{Ni}(\mathrm{II})$ $>\mathrm{Co}(\mathrm{II})>\mathrm{Cd}(\mathrm{II})$.

A unique 3D hierarchical flower-like GO/hydroxyapatite (HAp) was represented [88] (Fig. 1). HAp $\left[\mathrm{Ca}_{10}\left(\mathrm{PO}_{4}\right)_{6}(-\right.$ $\mathrm{OH})_{2}$ ] is the fundamental biological mineral in human body and exists in hard tissues such as bones and teeth. Biomimetic method was applied in this research to monitor the process that HAp grew on GO. GO was immersed in simulated body fluid (SBF) for 7 days of incubation. This produced high adsorption capacity $\left(\mathrm{q}_{\mathrm{e}}\right)$ in the acidic environment, where the predominant species were $\mathrm{POH}^{0}$ and $\mathrm{CaOH}_{2}{ }^{+}$. The plausible explanation could be the layered sorbent $\mathrm{K}_{2} \mathrm{MnSn}_{2} \mathrm{~S}_{6}$ (KMS-1) for $\mathrm{UO}_{2}{ }^{2+}$ treatment [61]. Since $\mathrm{Ca}^{2+}(0.103 \mathrm{~nm})$ is similar in the size with $\mathrm{Sr}^{2+}$ $(0.125 \mathrm{~nm})$, ion exchange was thought to be the main mechanism:

$\mathrm{HAp}-\mathrm{Ca}^{2+}+\mathrm{Sr}_{\mathrm{aq}}^{2+} \Leftrightarrow \mathrm{HAp}-\mathrm{Sr}^{2+}+\mathrm{Ca}_{\mathrm{ap}}^{2+}$
$\mathrm{HAp}-\mathrm{OH}+\mathrm{Sr}_{\mathrm{aq}}^{2+} \Leftrightarrow \mathrm{HAp}-\mathrm{O}-\mathrm{Sr}^{2+}+\mathrm{H}_{\mathrm{aq}}^{+}$
$2 \mathrm{HAp}-\mathrm{OH}+\mathrm{Sr}^{2+} \Leftrightarrow(\mathrm{HAp}-\mathrm{O})_{2} \mathrm{Sr}+2 \mathrm{H}^{+}$

Another strategy to adsorb $\mathrm{Sr}^{2+}$ is reversible additionfragmentation chain transfer (RAFT) polymerization on 
GO [60]. Compared with traditional polymerization technology, RAFT supports the ion-imprinted surface of GO to make a homogeneous thin layer with controllable and living features. The maximum adsorption capacity acquired from imprinted polymer was four times higher $(146 \mathrm{mg} / \mathrm{g})$ than from non-imprinted one.

\section{Characterization}

Nanocarbon has been developed from nanodiamond to 3D graphene. Along this line, there are other types of nanocarbons, such as fullerene C60, fullerene C540, carbon onion, single-walled nanotube (SWNT), and multiwalled nanotube (MWNT). For the purpose of environmental remediation, both individual properties (e.g., electronic conductivity) and bulk properties such as surface area are of the importance. Nanotubes exhibit superior sorptive properties for low molecular weight and polar molecules due to hydrophilic groups, $-\mathrm{OH}$ and $-\mathrm{COOH}$, as compared to activated nanocarbon. Nanotubes with aligned structures cause quantum confinement in the radial and circumferential direction [48] so that the desalination feature was constrained. GO derivatives and other types of novel nanocarbon were developed in the last decade [52].

\section{Mechanisms of removing contaminants}

For treatment of wastewater, the mechanism includes either physisorption or chemisorption of the adsorbates. Adsorption isotherms are usually modeled on series of classic models, which could explain the sorption processes at a macrolevel. Four sorption models, Langmuir, Freundlich, Redlich-Peterson, and Temkin, were attempted to illustrate the isotherm [68]. Langmuir could picture a monolayer sorption on the sorbent without any migration of the sorbate into the sorbent [23]. Freundlich depicts the reversible sorption which is not restricted to monolayer sorption [66]. Redlich-Peterson assumes that at low concentration, the isotherm approximates to Langmuir and at high concentration, it is prone to Freundlich [68]. Temkin takes into account the interaction between the sorbent and sorbate explicitly, which describes that the heat of sorption would decrease linearly with coverage rather than logarithmically [47]. The regression square $\left(\mathrm{R}^{2}\right)$ was compared for each metal $\mathrm{Cu}^{2+}, \mathrm{Cd}^{2+}, \mathrm{Co}^{2+}$, and $\mathrm{Cr}^{3+}$. Besides, parameter $\mathrm{n}$ from Freundlich was found to be $>2$, which favored physisorption and the maximum adsorption capacity $\left(\mathrm{q}_{\max }\right)$ could be calculated based on experimental data with Langmuir model.

Four comprehensive kinetic models were used to describe the adsorption kinetics as well: pseudo-first-order, pseudo-second-order, Elovich, and the intra-particle diffusion models. Pseudo-second-order model indicated that the chemisorption was predominant, and there was no interaction between sorbates. Elovich model implied the multilayer adsorption, and the sorption sites increased exponentially as the adsorption proceeded [5]. The intraparticle diffusion model assumed the high concentration of solutes surrounding the sorbent, the mass transfer, and the low concentration of solute in some surface sites where the adsorption extremely slowed down [76].

GO is an outstanding material for the treatment of heavy metal-contaminated water due to its abundant oxygen groups on the surface [80]. Th(IV) is an analog of tetravalent actinides. Studies using Th or Th(IV) could provide the surface and subsurface information of more radioactive materials. The interaction between GO and Th(IV) was studied experimentally and modeled with density functional theory (DFT), which is a quantum mechanism modeling method investigating electron structures [13]. The high sorption capacity occurred at $\mathrm{pH} 2.6$ with $215 \mathrm{mg} / \mathrm{g}$. $\mathrm{Th}^{4+}$ was found in the form of the adsorbate instead of oxide or hydroxide precipitate with extended X-ray adsorption fine structure (EXAFS). To find the binding nature between Th(IV) and GO, Mayer bond order analysis [36] was performed, resulting in Th-O from all structures that DFT predicted, indicating a significant ionic character and electrostatic interactions. DFT also revealed that the bond lengths of Th-O were different between the hydroxyl oxygen and carboxyl oxygen. The bond length of $\mathrm{Th}-\mathrm{O}$ (hydroxyl) was longer than that of Th-O(carbonyl), indicating that carboxyl oxygen had stronger coordination with Th(IV) than hydroxyl oxygen did.

The study on functionalization of GO through hydroxyl, carboxyl, and epoxy groups provides much insight into the adsorption and desorption of $\mathrm{U}(\mathrm{VI})$ on GO [81]. Zeta potential was tested at different $\mathrm{pHs}$, and negative values were found across a wide range for $\mathrm{GO}$ and $\mathrm{HOOC}-\mathrm{GO}$, indicating an electrostatic attraction between negatively charged adsorbents and the cation U(VI). The ionic strength effect was also demonstrated for various pHs, when each adsorbent, GO, GO-COOH, and reduced $\mathrm{GO}(\mathrm{rGO})$, was prepared under 0.1 and $0.01 \mathrm{M} \mathrm{NaNO}_{3}$. A slight difference was observed when $\mathrm{pH}$ was $>4$ since inner sphere surface complexation possibly dominated the adsorption. Density functional theory (DFT) was employed to measure the binding energy (BD), which was $8 \mathrm{kcal} / \mathrm{mol}$ for $\left[\mathrm{G} \cdots \mathrm{UO}_{2}\right]^{2+}$, indicating that the adsorption of $\mathrm{U}(\mathrm{VI})$ on rGO was physical adsorption. The higher binding values of $\left[\mathrm{GOs} \cdots \mathrm{U}(\mathrm{OH}) \mathrm{O}_{2}\right]^{2+} \quad(46 \mathrm{kcal} / \mathrm{mol})$ and $[\mathrm{GOs}-\mathrm{OH} \cdots$ $\left.\mathrm{U}(\mathrm{OH}) \mathrm{O}_{2}\right]^{2+}(43 \mathrm{kcal} / \mathrm{mol})$ indicated the abstraction of oxygen from $\mathrm{U}(\mathrm{VI})$ in chemisorption (Fig. 2).

GO assisted the reduction of $\mathrm{U}(\mathrm{VI})$ on nano-zero-valent iron/GO (nZVI/GO) [79]. For the sorbent, nZVI transformed from magnetite/maghemite to lepidocrocite under the retardation of corrosion production, which was 


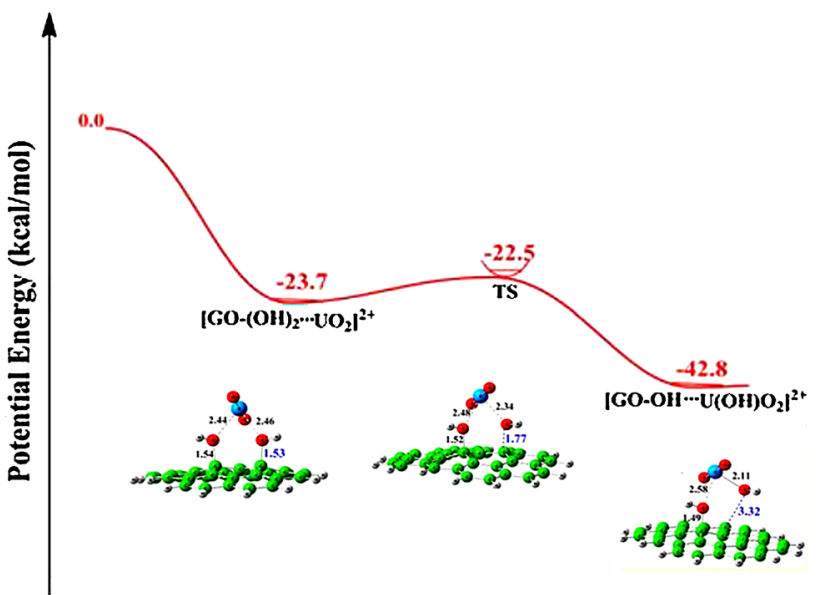

Fig. 2 DFT-simulated binding mechanisms between U and GO. The lower the energy, the shorter the bond length of oxygen from $\mathrm{UO}_{2}{ }^{2+}$ and the functional groups on GO (Modified from [81])

observed from X-ray diffraction spectra (XRD). A pH study revealed that enhanced adsorption was due to the positive charge of $\mathrm{U}(\mathrm{VI})$-containing species including $\mathrm{UO}_{2}{ }^{2+}, \mathrm{UO}_{2} \mathrm{OH}^{+}$, and $\left(\mathrm{UO}_{2}\right)_{3}(\mathrm{OH})_{5}^{+}$in an acidic environment. In the contrast, the attenuated sorption was attributed to alkaline conditions in which $\mathrm{U}(\mathrm{VI})$ existed as $\mathrm{UO}_{2}(\mathrm{OH})_{3}^{-},\left(\mathrm{UO}_{2}\right)_{3}(\mathrm{OH})_{7}^{-}$, and $\mathrm{UO}_{2}(\mathrm{OH})_{4}^{2-}$.

GO used as a membrane functioned adequately in the filtration of wastewater. The animated GO was layered onto polyvinylidene fluoride (PVDF) membrane, and the multilayered membrane was investigated for the efficacy of $\mathrm{Co}^{2+}$ removal [34]. A zeta potential study confirmed the presence of a negatively charged surface when the $\mathrm{pH}$ was above 4 , which was suitable for heavy metal removal, with a relatively high adsorption capacity of $116 \mathrm{mg} / \mathrm{g}$. However, a poor selection for $\mathrm{Co}^{2+}$ was reported in the presence of $\mathrm{Ca}$ and $\mathrm{Mg}$ ions.

The sorbate oxidation state and the sorption progress could be detected from X-ray photoelectron spectroscopy (XPS) [79]. U 4f peak was detected on XPS, which could be quantitatively resolved by two states, U(VI) at $382 \mathrm{eV}$ and $\mathrm{U}(\mathrm{IV})$ at $380.8 \mathrm{eV}$. Comparing nZVI/rGO-2 with $\mathrm{nZVI} / \mathrm{rGO}-60$, the conversion of $\mathrm{U}(\mathrm{VI})$ to $\mathrm{U}(\mathrm{IV})$ was obvious, indicating that the reduction occurrence was more after 60 days than after 2 days.

Besides GO, other nanocarbons made of cyclic molecules such as sugar display suitable contaminant binding characteristics. Nowadays, the simultaneous adsorption of metal ions and dyes was developed and only a few had a good potential due to the inevitable competition of those ions to free adsorption sites. Cyclodextrin (CD) was a good source for the capture of organic molecules, and EDTA is a good chelating agent for metal ions. The CD-EDTA polymer was synthesized as the adsorbent for $\mathrm{Cu}(\mathrm{II}), \mathrm{Cd}(\mathrm{II})$, which were both used as mordants in the dyeing process [methylene blue (MB), Safranin O (SO), and crystal violet (CV)]. Compared with other cross-linked materials such as epichlorohydrin (EPI), EDTA outperformed for all the pollutants above in terms of the adsorption capacity [96].

Hydrothermal carbon spheres (HCS) grafted with phosphate group was studied. O-phosphoethanolamine was chosen as the phosphate group, and obvious evidence could be seen with SEM since the surface of HCS was chapped after the grafting. There is evidence on the selectivity to adsorption of $\mathrm{U}(\mathrm{VI})$ over other ions such as $\mathrm{Mg}(\mathrm{II}), \mathrm{Na}(\mathrm{I})$, $\mathrm{Zn}(\mathrm{II}), \mathrm{Mn}(\mathrm{II}), \mathrm{Co}(\mathrm{II}), \mathrm{Ni}(\mathrm{II}), \mathrm{Sr}(\mathrm{II}), \mathrm{Cs}(\mathrm{I})$, and $\mathrm{Hg}(\mathrm{II})$. Equation 4 was used to estimate the selectivity of $\mathrm{U}(\mathrm{VI})$ :

$S_{\mathrm{UO}_{2}^{2+} / M^{n+}}=\frac{K_{d}^{\mathrm{UO}_{2}^{2+}}}{K_{d}^{M^{n+}}}$

And the relative selectivity was calculated by:

$S_{r}=\frac{S_{H C S-\mathrm{PO}_{4}}}{S_{H C S}}$

Results showed that both $S_{\mathrm{UO}_{2}^{2+} / M^{n+}}$ and $S_{\mathrm{r}}$ were $>1$, indicating higher selectivity of the functionalized HCS for $\mathrm{U}(\mathrm{VI})$ rather than other ions [92].

\section{Development of mesoporous materials}

\section{Synthesis}

Silica-doped nanomaterials actively play a role in remediating the wastewater besides nanocarbon. Magnetite-silica composite has been synthesized for the adsorption of several radionuclides, $\mathrm{Co}^{2+}, \mathrm{Sr}^{2+}$, and $\mathrm{Cs}^{2+}$ [26]. A significant improvement was $20 \%$ silica (mass percent) in the composite that improved adsorption capacity. Even under extreme $\mathrm{pH}$ conditions, the adsorption was still efficient, which was in contrast to the performance of very selective and expensive adsorbents. It was also notable that $\mathrm{K}_{\mathrm{d}}$ of this adsorbent was 10-1000 times lower, making it suitable for the large-scale treatment needs. As a transition metal, $\mathrm{Co}^{2+}$ did not represent high competition with the background electrolyte $\mathrm{Na}^{+}$, which contradicted with alkaline metals $\mathrm{Sr}^{2+}$ and $\mathrm{Cs}^{+}$.

The nanosized spherical cavity of silica not only provides high surface area, but also makes the binding sites for specific ligands accessible. $N, N$ (octane-1,8-diyli-dene)di(2hydroxyl-3,5-dimethylaniline) was a good indicator for $\mathrm{Co}^{2+}$ due to the $\pi-\pi$ transition, making a visible color change from white to green and the heteroatoms in which imposed an electrostatic interaction with silica. The optimum $\mathrm{pH}$ for this adsorbent was 8 since as $\mathrm{pH}$ increased and the surface of the adsorbent became more negatively charged, which was conducive to the binding of $\mathrm{Co}^{2+}$ [10] (Fig. 3). 
(a)
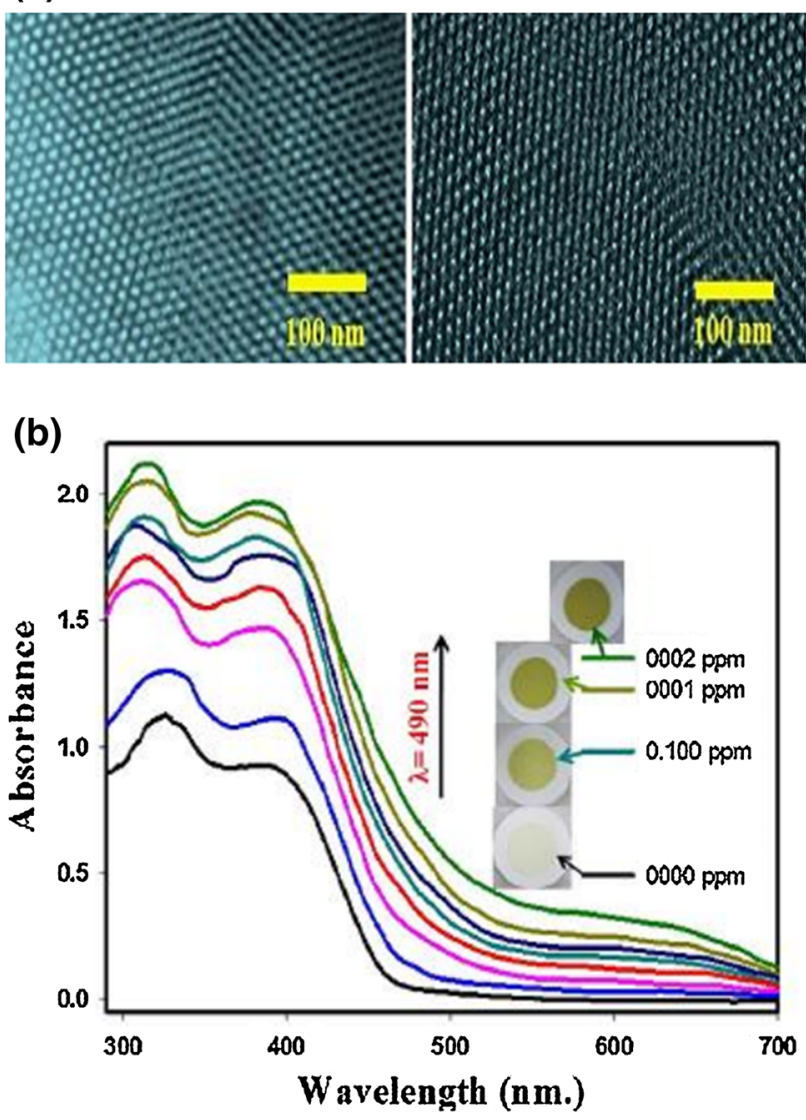

Fig. 3 TEM images clearly shows that the DHDM-embedded mesosilica (b) preserved the hexagonal porous structure from mesosilica (a). DHDM has played a significant role in $\mathrm{Co}^{2+}$ detection. The lowest concentration of $\mathrm{Co}^{2+}$ is shown on the bottom spectrum, and the highest concentration is on the top (Modified from [10] (Copyright from Elsevier))

Mesoporous materials could be regarded as an essential additive onto $\mathrm{GO}$ to enhance the stability and resistance under various ionic strengths [78]. Mesoporous $\mathrm{Al}_{2} \mathrm{O}_{3} / E G$ (expanded graphene) for the sorption of $\mathrm{Eu}(\mathrm{III})$ has been synthesized. $\mathrm{Al}_{2} \mathrm{O}_{3}$ intercalated into the graphene, which changed the low-density character of GO so that GO possessed abundant epoxy groups. The lamellar structure resulted in high stability due to the reduction of interaction between $\mathrm{H}^{+} / \mathrm{OH}^{-1}$ and $\mathrm{Al}_{2} \mathrm{O}_{3}$ from $\mathrm{pH} 2-8$.

Functionalized mesosilica could meet the needs of largescale and cheap detection in industry. A 6-((2-(2-hydroxy1-naphthoyl)hydrazono)methyl)benzoic acid (HMBA) mesosilica composite was synthesized as the sorbent for $\mathrm{Cu}$ (II) and $\mathrm{Pd}$ (II) [7]. The optimal pHs for color detection of $\mathrm{Cu}(\mathrm{II})$ and $\mathrm{Pd}(\mathrm{II})$ were 5.2 and 3.5, respectively, which was resulted from the charge transfer and the intense $\pi-\pi$ transition. In addition, suitable ligands made the optimal $\mathrm{pH}$ highly selective for $\mathrm{Cu}$ (II) and $\mathrm{Pd}(\mathrm{II})$, which was shown by using $0.25 \mathrm{M} \mathrm{HCl}$ to strip up to $98.5 \% \mathrm{Cu}$ (II), whereas
Pd(II) was not expected to be stripped out even when $2.5 \mathrm{M} \mathrm{HCl}$ was used, but undesired trace amount of other metal ions could be eluted out. Therefore, for Pd(II) elution, $2 \mathrm{M} \mathrm{HCl}$ was applied first to remove all other trace ions, and then $0.1 \mathrm{M} \mathrm{HCl}$-thiourea was applied to extract pure Pd(II). This could lead to the use in the recycling of $\mathrm{Pd}(\mathrm{II})$, an important industrial catalyst, especially as an automobile catalyst converter. Besides, it was also a radioactive fission product $[8,9]$.

Mesoporous silica-carbon composite is another competitive material which outworked functionalized mesosilica in many cases. Carboxyl-functionalized mesosilica-carbon composite was synthesized with a carbonization-oxidation procedure [85]. The adsorption capacity was compared when mesosilica, unoxidized silica-carbon composite, and oxidized silica-carbon composite were applied for the adsorption of $\mathrm{Zn}(\mathrm{II}), \mathrm{Pb}(\mathrm{II})$, and $\mathrm{Cu}(\mathrm{II})$. The oxidized composite outperformed the other two materials.

The mesosilica hybrid material could also be a suitable matrix which contains backbone structural groups such as phosphonate and phosphate. Silica-phosphonate, an alternating layer structural hybrid, was synthesized from xerogel formation for water treatment of $\mathrm{Cu}(\mathrm{II}), \mathrm{Pb}(\mathrm{II})$, and $\mathrm{Cd}(\mathrm{II})$. The multilayered stacking was confirmed from TEM and SEM. The maximum metal uptake was determined to be $2.72 \mathrm{mmol} / \mathrm{g} \mathrm{Cu}$ (II), $1.67 \mathrm{mmol} / \mathrm{g} \mathrm{Pb}$ (II), and $1.00 \mathrm{mmol} / \mathrm{g} \mathrm{Cd}(\mathrm{II})$ at $\mathrm{pH} 7$ [21].

The formation of cross-linked organic-inorganic mesosilica hybrid composites was always hindered due to organic groups in the porous walls, leading to the collapse of pore structure. To solve this, cross-linked 2,6-diamino pyridine and tetraethyl orthosilicate were used as the silica source, which was then modified with chlorosulfonic acid. This composite was confirmed to be selective for Co(II), mediating the needs of Co in the core industry [41].

Self-transformation strategy was proposed to open up a new avenue for heavy metal removal [86]. Compared with other hard-templating procedures [20,33], this method had many advantages such as no post-removal of the template and co-polymerization with melamine to promote the meso-scale structure with N-doping. Self-transformation entailed that melamine sulfate in situ transformed into carbonaceous flakes from continuous dissolution, cracking, deposition, self-assembly, and cross-linking. This material was affirmed to be prospected in the adsorption of $\mathrm{Mn}(\mathrm{II})$, $\mathrm{Fe}(\mathrm{III}), \mathrm{Ni}(\mathrm{II}), \mathrm{Co}(\mathrm{II}), \mathrm{Cu}(\mathrm{II})$, and $\mathrm{Pb}(\mathrm{II})$.

\section{Characterization of mesosilica}

The unique structure of carboxyl-functionalized mesoporous silica-carbon composites was characterized [85]. SEM was chosen to reveal that the oxidized nanocarbon consisted of a bundle of carbon rods which indicated that 
the carbon source was exclusively impregnated into the pores of silica. Furthermore, TEM backed up the structure since after carbonization-oxidation; the finely tuned pores were clearly seen. Furthermore, X-ray photoelectron spectroscopy (XPS) was chosen to exhibit $\mathrm{C} 1$ and $\mathrm{O} 1 \mathrm{~s}$ spectra, which was worth noting that most of the oxygen existed as hydroxyl groups before oxidation, but after that, the majority of them existed as carboxylic groups. Besides, temperature-programmed desorption (TPD) which was cooperated with a mass spectrometer (MS) exhibited the profiles on releasing $\mathrm{CO}$ and $\mathrm{CO}_{2}$. In this way, the oxygen functional groups were quantitatively measured as carboxyl groups $(0.5 \mathrm{mmol} / \mathrm{g})$, carboxyl anhydrides $(0.6 \mathrm{mmol} / \mathrm{g})$, phenol $(0.4 \mathrm{mmol} / \mathrm{g})$, lactone $(0.1 \mathrm{mmol} / \mathrm{g})$, and carbonyl/quinone $(0.1 \mathrm{mmol} / \mathrm{g})$ (Fig. 4$)$.

Thermogravimetric analysis (TGA) is applied to detect the morphology of mesosilica. Below $330{ }^{\circ} \mathrm{C}$, an absence of the weight loss implied the condensation of silicate network and the minor fraction of $\mathrm{Si}-\mathrm{OH}$. The majority of silicate represented $\mathrm{Si}-\mathrm{O}-\mathrm{Si}$ bridge form [21].

Brunauer-Emmett-Teller (BET) is a classic method to measure the pore volume and surface area. Combined with small-angle X-ray scattering (SAXS), using the equation as follows:

$\emptyset=1.2 d_{100}\left(\frac{\rho V_{p}}{1+\rho V_{p}}\right)^{1 / 2}$

the pore diameter $(\Phi, \mathrm{nm})$ could be acquired accurately [22]. In BET, compared with the pristine material isotherms, the material after pore filling still preserved the cylindrical pore system. The isotherm after pore filling was identical with that of the pristine material on SAXS. Remarkably, in simulated Fukushima radionuclide-contaminated seawater with $29 \mathrm{kBq} / \mathrm{L} \mathrm{Cs}, \mathrm{K}_{\mathrm{d}}$ for Prussian blue $\left(\mathrm{Co}^{2+} /\left[\mathrm{Fe}(\mathrm{CN})_{6}\right]_{3}^{2-}\right)$-mesosilica composite was

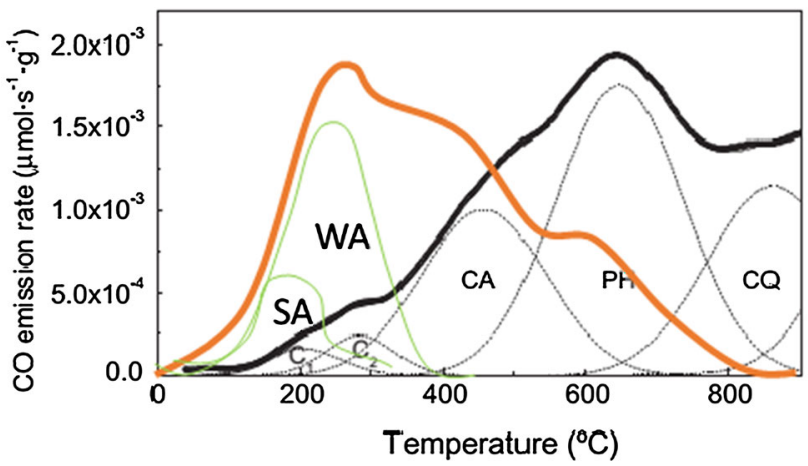

Fig. 4 TPD (temperature-programmed desorption) confirmed various carbonyl groups on the mesoporous silica-carbon composite. The black curve specifies the profile of $\mathrm{CO}$; meanwhile, orange curve denotes the profile of $\mathrm{CO}_{2}$. WA weakly acidic carboxyl groups, $S A$ strongly acidic carboxyl groups, $C A$ carboxyl anhydrides, $P H$ phenols, $C Q$ carbonyl/quinone functionalities (Modified from [85])
$8 \times 10^{5} \mathrm{~mL} / \mathrm{g}$ compared with bare Prussian blue $\left(6 \times 10^{5} \mathrm{mg} / \mathrm{L}\right)$, indicating the selectivity of the composite. Besides, after filling into the pores of mesosilica, Prussian blue adsorbed Cs ten times faster and produced three times higher adsorption capacity.

To explore how well elementally doped mesosilica could perform ion exchange, pristine mesosilica was compared with mesosilica doped with boron, aluminum zinc, or mesosilica modified with various carbon-chain-length templates for the treatment of ${ }^{57} \mathrm{Co},{ }^{89} \mathrm{Sr}$, and ${ }^{137} \mathrm{Cs}$. Since common $\mathrm{Na}^{+}$might not be in the active sites of the sorbent, ${ }^{22} \mathrm{Na}$ was chosen as the label to study the ion exchange capacity. Besides, sodium tetraborate and trisodium citrate were applied as the complexing agents. Since radioisotopes were employed in this study, $\mathrm{K}_{\mathrm{d}}$ was modified as:

$K_{d}=\left(A_{0}-A\right) / A \cdot V / m$

where A represents activity $(\mathrm{Bq} / \mathrm{ml})$. The $\mathrm{K}_{\mathrm{d}}$ value was significant to evaluate mesosilica doped with heteroatoms or composited with various chain-length templates. This study profoundly exhibited the tunable nature of mesosilica [25].

Continuously, the tunable nature of mesosilica was again affirmed by the accommodation with other functional groups from the halide system to the macrocyclic system P-M1 and P-M2, involving several steps of the sol-gel process. P-M1, which was polysiloxane-immobilized macrocyclic 1,4,7,11,14-pentaaza-pentadecane-3,15-dione ligand system, was proved to have a higher potential for the extraction or pre-concentration to $\mathrm{Fe}^{3+}, \mathrm{Co}^{2+}, \mathrm{Ni}^{2+}, \mathrm{Cu}^{2+}$, and $\mathrm{Zn}^{2+}$ after immobilized in mesosilica [30]. Synthesis, characterization, and application of polysiloxane-immobilized ligand systems were thoroughly categorized [29].

\section{Adsorption mechanism of heavy metals}

The sorption of heavy metals on some sorbents could be explained in surface complexation. Mesoporous calciumsilica from coal fly was synthesized for the removal of $\mathrm{Co}(\mathrm{II})$. The amount of $\mathrm{Ca}$ in the composite had a significant influence on the sorption capacity when increased from 180 to $291 \mathrm{mg} / \mathrm{g}$ when $41 \% \mathrm{Ca}$ was added in. The mechanism of the sorption included several major steps. Firstly, hydrated Co(II) was surface-complexed, which then went through intra-particle diffusion, and in the interlayer, the coordinated water was lost and became exchangeable, $\mathrm{Co}$ (II) with $\mathrm{Ca}$ (II). The application of this sorbent in radioactive wastewater treatment was highlighted since it could play a partial substitute in cement in solidification/ stabilization procedure, making Co(II) further exchanged with $\mathrm{Ca}$ (II) in the matrix. This significantly reduced the mass of material produced so that the landfill space would be maximized [73]. 
The interaction between $\mathrm{Cr}(\mathrm{III})$ and $\mathrm{Fe}_{3} \mathrm{O}_{4}$ /mesosilica complex was studied, especially on surface morphology change. The optimum $\mathrm{pH}$ of adsorption was tested to be 5.4. The positive trend of zeta potential elucidated the form of adsorbed $\mathrm{Cr}(\mathrm{III})$ as $\mathrm{Cr}(\mathrm{OH})_{2}^{+}$and $\mathrm{Cr}(\mathrm{OH})^{2+}$. TEM/EDS quantitatively unveiled the difference of $\mathrm{Fe}_{3} \mathrm{O}_{4}$-MCM-41$\mathrm{NH}_{2}$ and $\mathrm{Fe}_{3} \mathrm{O}_{4}-\mathrm{MCM}-41$ in adsorbed $\mathrm{Cr}(\mathrm{III})$. Besides, XPS supplemented elemental analysis. However, the protonated surface of amine group did not adsorb anions such as chromate $\left(\mathrm{CrO}_{4}{ }^{2-}\right)$ and arsenate $\left(\mathrm{AsO}_{4}{ }^{3-}\right)$. Since electronic static was not the explanation for this phenomenon, the selectivity of amine groups to $\mathrm{Cr}$ (III) played a significant role [27].

The element-specific short-range structure, the coordination number, bond distance, and type of near neighbors could be known from extended X-ray absorption fine structure (EXAFS). The decrease in the bond distance of $\mathrm{Eu}(\mathrm{III})-\mathrm{O}$ with the increase in $\mathrm{pH}$ could indicate that the outer sphere complexation shifted to inner sphere complexation based on EXAFS [78]. The estimated coordination number was $\sim 5$ between $\mathrm{U}(\mathrm{VI})$ and the equatorial oxygen [58]. It was affirmed there was a sharp peak at $1.9 \AA$, which corresponded to the phase-corrected value 2.4-2.5 ̊. Three samples were studied, and the coordination numbers were approximately the same from 8.1 to 8.7 as oxygen. This may indicate that lamellar structure of the sorbent hindered the full accessibility of Th(IV) to oxygen based on EXAFS [13].

The oxidation state and morphology of actinides and lanthanides on novel sorbents have premier significance on the understanding of the interaction between radionuclides and the sorbent. FDU-16 and C-CS, two kinds of mesoporous carbon, and their oxidized counterparts, were selected to target $\mathrm{Pu}(\mathrm{VI})$ and $\mathrm{Eu}(\mathrm{III})$ [71]. On TEM, XANES, and $\mathrm{XAS}$, pristine nanocarbon was found to reduce $\mathrm{Pu}(\mathrm{VI})$ to $\mathrm{Pu}(\mathrm{IV})$ efficiently. Though C-CS and C-CS-COOH both were able to reduce $\mathrm{Pu}(\mathrm{VI})$ to $\mathrm{Pu}(\mathrm{IV}), \mathrm{C}-\mathrm{CS}$ could exclusively reduce $\mathrm{Pu}(\mathrm{VI})$ to $\mathrm{PuO}_{2}$. Linear combination analysis (LCS) with XANES confirmed that for both C-CS and $\mathrm{C}-\mathrm{CS}-\mathrm{COOH}, \mathrm{Pu}$ existed as a tetravalent ion.

Three types of phosphoric acid modified silica, SBA$\mathrm{POH}, \mathrm{MCM}-\mathrm{POH}$, and BPMO-POH, were employed for the sorption of $\mathrm{Am}(\mathrm{III})$ and $\mathrm{Eu}(\mathrm{III})$ [94]. The coordination number was obtained from EXAFS. It was found that at $\mathrm{pH}$ 0.7 and 3.2, phosphonic acid as a bidentate bound to $\mathrm{Eu}(\mathrm{III})$, resulting in the Eu-O coordination number of 7 . Besides, binding energy (BE) for $\mathrm{Eu}\left(\mathrm{NO}_{3}\right)_{2}$ was $1136 / 1126 \mathrm{eV}$ when Eu 3d5/2 was measured from XPS [62]. Based on Pauling's electronegativity scale, the electronegativity for nitrogen and phosphorous was 3.04 and 2.19, respectively [72]. BE for Eu-laden SBA-POH was much lower than the value of $\mathrm{Eu}\left(\mathrm{NO}_{3}\right)_{2}$, indicating that $\mathrm{Eu}$ bound with phosphorous instead of nitrogen. Therefore, the binding between phosphonic functional groups and $\mathrm{Eu}(\mathrm{III})$ was confirmed.

Several main mesosilica, KIT-6, SBA-15, and SBA-16, were applied to study the effectiveness and complexation rate with divalent ions [32]. Aminopropyl groups were grafted to each kind of mesosilica. Carboxyl groups were quantitatively characterized from back-titration [38], which required the transformation of $\mathrm{COONa}$ groups to $\mathrm{COOH}$ groups first, subsequently, the dispersion into the standard $\mathrm{NaHCO}_{3}$ solution, and then the titration with the standard $\mathrm{HCl}$ solution. To examine the selectivity of each adsorbent, the following equation was used:

$\alpha_{\mathrm{Cu} / \mathrm{Pb}}=\frac{X_{\mathrm{Cu}}}{Y_{\mathrm{Pb}}} \cdot \frac{Y_{\mathrm{Cu}}}{X_{\mathrm{Pb}}}$

where $\mathrm{X}$ denotes the adsorbed molar fraction and $\mathrm{Y}$ denotes the molar fraction remaining in the solution. There was no adsorption of $\mathrm{Ni}(\mathrm{II})$ and $\mathrm{Cd}(\mathrm{II})$, and $\alpha$ equaled 0.61 and 0.88 for SBA and KIT composite, respectively, indicating that $\mathrm{Pb}(\mathrm{II})$ was selected more from both sorbents. The selectivity was mainly based on the kinetic factor, which was determined with the exchange velocity between the sorbent and hydrated ions. Besides, the high complexation constant for EDTA led to less likely spontaneous desorption of $\mathrm{Cu}(\mathrm{II})$ and $\mathrm{Pb}(\mathrm{II})$.

\section{Development of magnetic materials}

\section{Synthesis}

The hollow structure of mesoporous magnetic material was developed through synthesis [54]. Sodium acetate was used to initiate the primary crystalline nucleation and as the structure-directing agent. Polyvinylpyrrolidone (PVP) acted as the capping agent and surfactant. A solvothermal method was implemented, where the solution was put into a Teflon-lined stainless steel autoclave and heated at $200{ }^{\circ} \mathrm{C}$ for $8 \mathrm{~h}$ [98]. A unique hollow cavity was formed from the Ostwald ripening process which involved crystallization-recrystallization and coalescing to make small spaces within the hollow cavity in accordance with Von Weimann rules [14]. Each of the nanospheres consisted of several subspheres enclosing the cavity. $\mathrm{pH}$ strongly affects the surface charge. When $\mathrm{pH}<\mathrm{pH}_{\mathrm{pzc}}$, point of zero charge, the sorbent surface was positively charged, and when $\mathrm{pH}>\mathrm{pH}_{\mathrm{pzc}}$, it was negatively charged. $\mathrm{pH}_{\mathrm{pzc}}$ equaled 2.1 for magnetic nanomaterials. Therefore, speciation of ions under various $\mathrm{pHs}$ was procured, which entailed that $\mathrm{CrO}_{4}{ }^{2-}$ was increasingly adsorbed below $\mathrm{pH} 2$, whereas the sorption of $\mathrm{Pb}^{2+}$ declined at the same $\mathrm{pH}$ range. In contrast, at $\mathrm{pH} 2-7$, there was an augmentation of electrostatic repulsion between $\mathrm{CrO}_{4}{ }^{2-}$ and the sorbent. 
A layered, double-hydroxide (LDH) fabricated magnetic $\mathrm{GO}$ was synthesized for the adsorption of arsenate. $\mathrm{Fe}_{3} \mathrm{O}_{4}$ was covalently grafted on $\mathrm{GO}$, and then $\mathrm{Mg} / \mathrm{Al} \mathrm{LDH}$ was hydrothermally assembled on. There was a strong electrostatic attraction between arsenate and the LDH layered structure. Besides, the ion exchange between intercalated anion in the layer and arsenate played a significant role as well. Layered double-hydroxide in this composite significantly contributed to the sorption capacity, as magnetic GO was reported to have a sorption capacity of only $6 \mathrm{mg} / \mathrm{g}$ arsenate, whereas the composite was $73 \mathrm{mg} / \mathrm{g}$ arsenate and $38 \mathrm{mg} / \mathrm{g}$ for LDH. Furthermore, magnetic separation was confirmed with the same partition efficiency as centrifugation [89].

\section{Characterization}

The magnetic property of sorbent composite was a significant parameter in controlling separation, which could be measured by a vibrating sample magnetometer (VSM). The study compared $\mathrm{Fe}_{3} \mathrm{O}_{4} @$ PANI-AmAzoTCA[4] (magnetic polymerized thiacalix) with $\mathrm{Fe}_{3} \mathrm{O}_{4}$ in accordance with hysteresis hoops. The saturation magnetization for bare $\mathrm{Fe}_{3} \mathrm{O}_{4}$ was $54 \mathrm{emu} / \mathrm{g}$, and that for the composite was $51 \mathrm{emu} / \mathrm{g}$, indicating that the functionalization slightly decreased the magnetization saturation so that the agglomeration of nanoparticles was reduced [68].

The change of the surface of adsorbents could explicitly be revealed from atomic force microscopy (AFM). The change of a supermagnetic nanocomposite based on thiacalix[4]arene and polyaniline was unveiled. Each 2D image was corresponded to another 3D image, in which the amplitude of peak-to-valley height was gauged. Before the adsorption of $\mathrm{Cu}(\mathrm{II})$, the height was $19 \mathrm{~nm}$, and after the adsorption, it became $41 \mathrm{~nm}$ so that the adsorption of $\mathrm{Cu}$ (II) on the functional groups was confirmed [68].

The conductivity is another parameter that could be measured to affirm the sorption of metal ions onto the sorbent, especially when polymers are involved. Polyaniline (PANI) was applied as the conducting polymer, which was conjugated to make the redox sites delocalized over a conjugated $\pi$ system. The conductivity of $\mathrm{Fe}_{3} \mathrm{O}_{4} @$ PANIAmAzoTCA[4] composite had a greater enhancement up to a hundred order of magnitude after the sorption of metal ions than before the sorption, showing the interaction between the electroactive metal ions and the polymer backbones [68].

\section{Adsorption mechanism}

The coordination detail of paramagnetic metal ions $\mathrm{Cu}$ could be manifested from electron paramagnetic resonance (EPR) [37, 84]. It was applied on the binding system of phosphonate group-mesosilica hybrid layer material (PSLM) with $\mathrm{Cu}(\mathrm{II})$. The geometrical deposition could be illustrated as clustering or pairing binding. This study showed that no clustering occurred and $\mathrm{Cu}(\mathrm{II})$ was bound on the oxygen on phosphonates. Besides, potentiometric acid titration was adopted for H-binding study, which exhibited a strong H-binding profile at $\mathrm{pH} \sim 2-3$. PSLM $_{1}$ was denoted as type 1 PSLM which was subscribed to $\mathrm{pK}_{\mathrm{a}}=2.5$. During the weak H-binding range, other two types, $\mathrm{PSLM}_{2}$ and $\mathrm{PSLM}_{3}$, were assigned to $\mathrm{pK}_{\mathrm{a}} \sim 2.4-2.6$ and 6.2-6.4, respectively [21].

Magnetic material not only is an exclusive separation agent, but also generates synergistic effects with other materials, or could even be a core material for the treatment of metal ions. Originally, magnetic material was not as proficient as other sorbents, especially $\mathrm{Fe}_{3} \mathrm{O}_{4}$-based materials. However, $\mathrm{Fe}_{3} \mathrm{O}_{4}$ with the modified morphology exhibited separation property and synergistic effects with GO. Hollow structure magnetic GO was synthesized from the electrostatic assembly of positively charged $\mathrm{Fe}_{3} \mathrm{O}_{4}$ (after the modification with 3-aminopropyltrimethoxysilane) and negatively charged GO. Under low pH, $\mathrm{Cr}(\mathrm{VI})$ existed as $\mathrm{HCrO}_{4}^{-}$, which was captured on the modified iron oxide composite, displaying its capability of attraction to hydronium ions. Therefore, the positive hydronium ions and $\mathrm{Fe}_{3} \mathrm{O}_{4}$ accelerated the sorption simultaneously. Moreover, this composite exhibited hollow structures filled with abundant micropores. The maximum adsorption capacity $\left(\mathrm{q}_{\max }\right)$ was $32 \mathrm{mg} / \mathrm{g}$ for $\mathrm{Cr}(\mathrm{VI})$, which was higher than that of microsphere $\mathrm{Fe}_{3} \mathrm{O}_{4}$ [59] (Fig. 5).

Magnetite GO for the immobilization of Eu(III) has been synthesized [57]. Magnetite was decorated for the separation. Addition of humic acid (HA) and fulvic acid (FA) increased the adsorption of $\mathrm{Eu}(\mathrm{III})$. At low pH, HA and FA changed the positive surface of the adsorbent to more negative one. However, at high $\mathrm{pH}, \mathrm{FA}$ and HA could hardly be adsorbed on the adsorbent due to electrostatic repulsion; FA and HA competed with the adsorbent for $\mathrm{Eu}(\mathrm{III})$ in the solution.

To investigate whether pore property or film diffusion was the controlling step of adsorption, the intra-particle diffusion model was established as:

$q_{t}=k_{\mathrm{id}} \times t^{0.5}+C_{\mathrm{id}}$

where $k_{\text {id }}\left(\mathrm{mmol} \mathrm{g}^{-1} \mathrm{~min}^{-0.5}\right)$ and $C_{\text {id }}$ are the rate constant and intercept at different diffusion stages, respectively. Magnetic chitosan cross-linked with EDTA or DTPA was applied for the sorption of $\mathrm{Cd}(\mathrm{II}), \mathrm{Pb}$ (II), $\mathrm{Co}$ (II), and $\mathrm{Ni}$ (II) [96]. After the model applied, three-stage linear portion indicated that the adsorption could be divided as external surface adsorption, mesopore diffusion, and micropore diffusion. If $K_{\mathrm{id}, 1}$ was higher than $K_{\mathrm{id}, 2}$ and $K_{\mathrm{id}, 3}$, the entering of metal ions from the bulky solution to the 
Fig. 5 SEM (a), TEM (b), and The inlet in Fig. a shows the hollow structure from HRSEM. The interplane distance of $2.51 \AA$ corresponds to (311) plane of $\mathrm{Fe}_{3} \mathrm{O}_{4}$ structure. On the $\mathrm{XRD}$ figure, the spectrum (black) of $\mathrm{Fe}_{3} \mathrm{O}_{4} / \mathrm{GO}$ displays many featured peaks of $\mathrm{Fe}_{3} \mathrm{O}_{4}$ rather than that of GO (Modified from [59] (Copyright from Royal Society of Chemistry)) $\mathrm{XRD}$ images of hollow structural $\mathrm{Fe}_{3} \mathrm{O}_{4} / \mathrm{GO}$ composite.
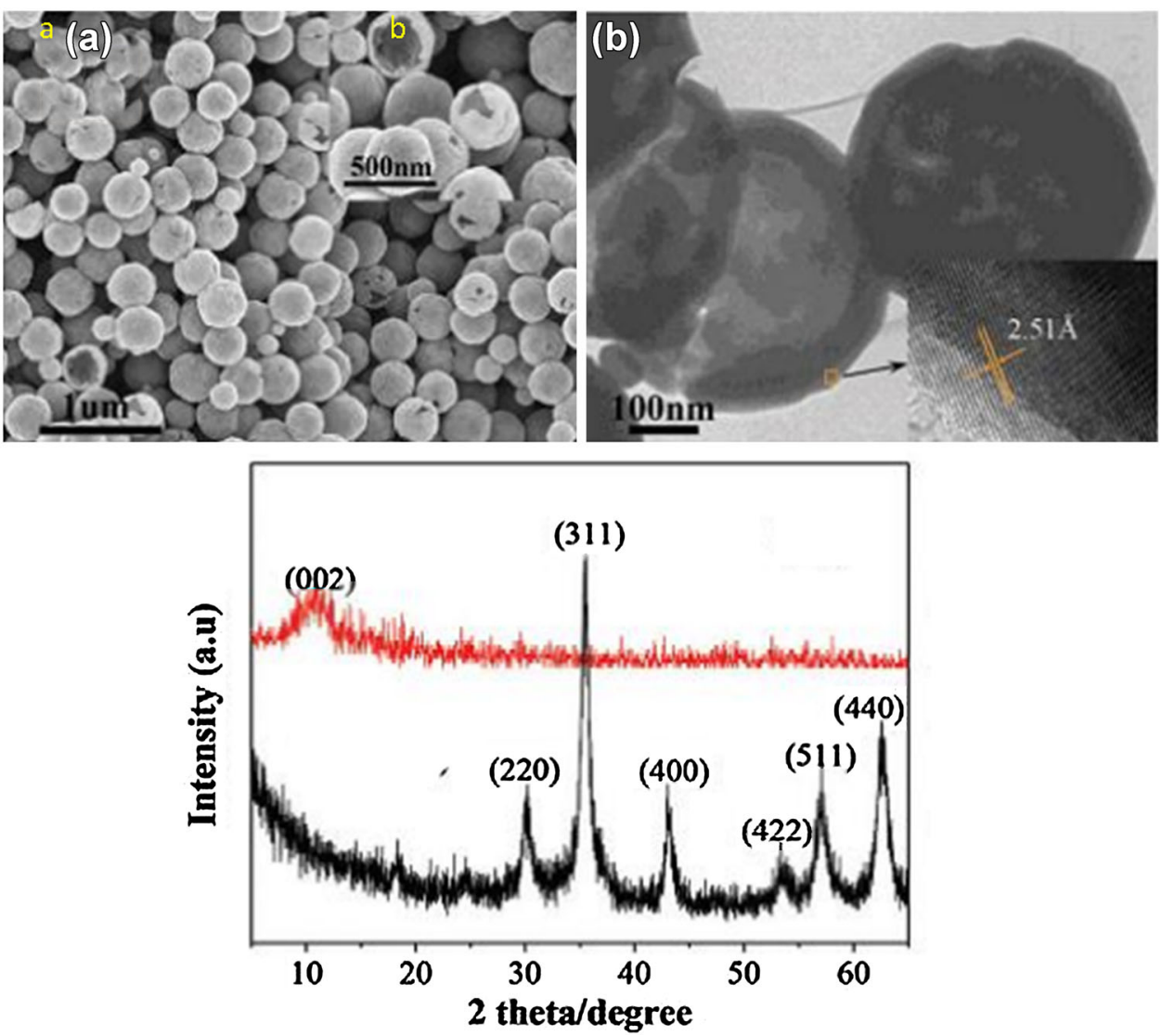

adsorbent exterior was the rate-controlling step. For the isotherm model, Sips isotherm model was applied:

$q_{e}=\frac{q_{m}\left(K_{S} C_{e}\right)^{n_{S}}}{1+\left(K_{S} C_{e}\right)^{n_{S}}}$

where $K_{\mathrm{S}}\left(\mathrm{L} \mathrm{mmol}^{-1}\right)$ is the Langmuir equilibrium parameter and $n_{\mathrm{S}}$ is comparable to Freundlich heterogeneity factor $n_{\mathrm{F}}$. This model proved to be viable when Langmuir and Freundlich models both failed. Besides, biLangmuir model assuming two active sites on the sorbent having divergent affinities to sorbates was applied to study adsorption of metals in nanomaterials [97]:

$q_{e}=\frac{q_{m, 1} K_{1 C_{e}}}{1+K_{1} C_{e}}+\frac{q_{m, 2} K_{2 C_{e}}}{1+K_{2} C_{e}}$

The calculated $\mathrm{q}_{\max }$ from Sips corresponded well to the experimental measurement than that of bi-Langmuir.

Magnetic composite was proved to be efficient to treat the wastewater with heavy metals at high oxidation state. Magnetic mesoporous carbon Fe/CMK-3 was synthesized [83]. Sucrose and $\mathrm{H}_{2} \mathrm{SO}_{4}$ were infiltrated into the pores of SBA-15 and then thermally treated twice to reach a maximized polymerization [95]. During the first $30 \mathrm{~min}$ of adsorption, $90 \%$ of $\mathrm{Cr}(\mathrm{VI})$ could be adsorbed onto $\mathrm{Fe} /$ CMK-3 compared with $70 \%$ of CMK-3. The equilibrium adsorption capacity was $98 \mathrm{mg} / \mathrm{g}$ for Fe/CMK-3 yet that of CMK-3 was $72 \mathrm{mg} / \mathrm{g}$. Thus, iron brought synergistic effect to the mesocarbon in the sorption of $\mathrm{Cr}_{2} \mathrm{O}_{7}{ }^{2-}$. Multivalent anions, $\mathrm{SO}_{4}{ }^{2-}$ and $\mathrm{PO}_{4}{ }^{3-}$, competed with sorption of $\mathrm{Cr}_{2} \mathrm{O}_{7}{ }^{2-}$ due to the similar size, decreasing the sorption capacity. Moreover, XPS confirmed that the oxidation state of $\mathrm{Cr}$ was three and $\mathrm{Cr}(\mathrm{OH})_{3}$ was the existent form instead of $\mathrm{Cr}_{2} \mathrm{O}_{3}$.

\section{Other nanosorbents}

Calixarene is usually an additive to the composite, which would be added in the last step with a relatively small amount. Nevertheless, the calixarene composite could be developed with the inverse perception, which synthesized calixarene core first and made the magnetic particle at last. Initially, $p$-tert-butyl-diaminoazo thiacalix[4]arene was synthesized, then SDS and DMSO were added to form the copolymer, and, at last, the magnetic particle was formed from in situ co-precipitation [68].

The Co and Cs adsorption on Mn oxides was studied on 2D FTIR (2D-COS-IR) (Fig. 6). The region where $\mathrm{M}^{\mathrm{n}+}$ / $\mathrm{nH}^{+}$exchange occurred and the inner sphere complex formed was confirmed. The band at $875 \mathrm{~cm}^{-1}$ was assigned for the two $\mathrm{O}-\mathrm{O}$ bond lengths, which evidenced 


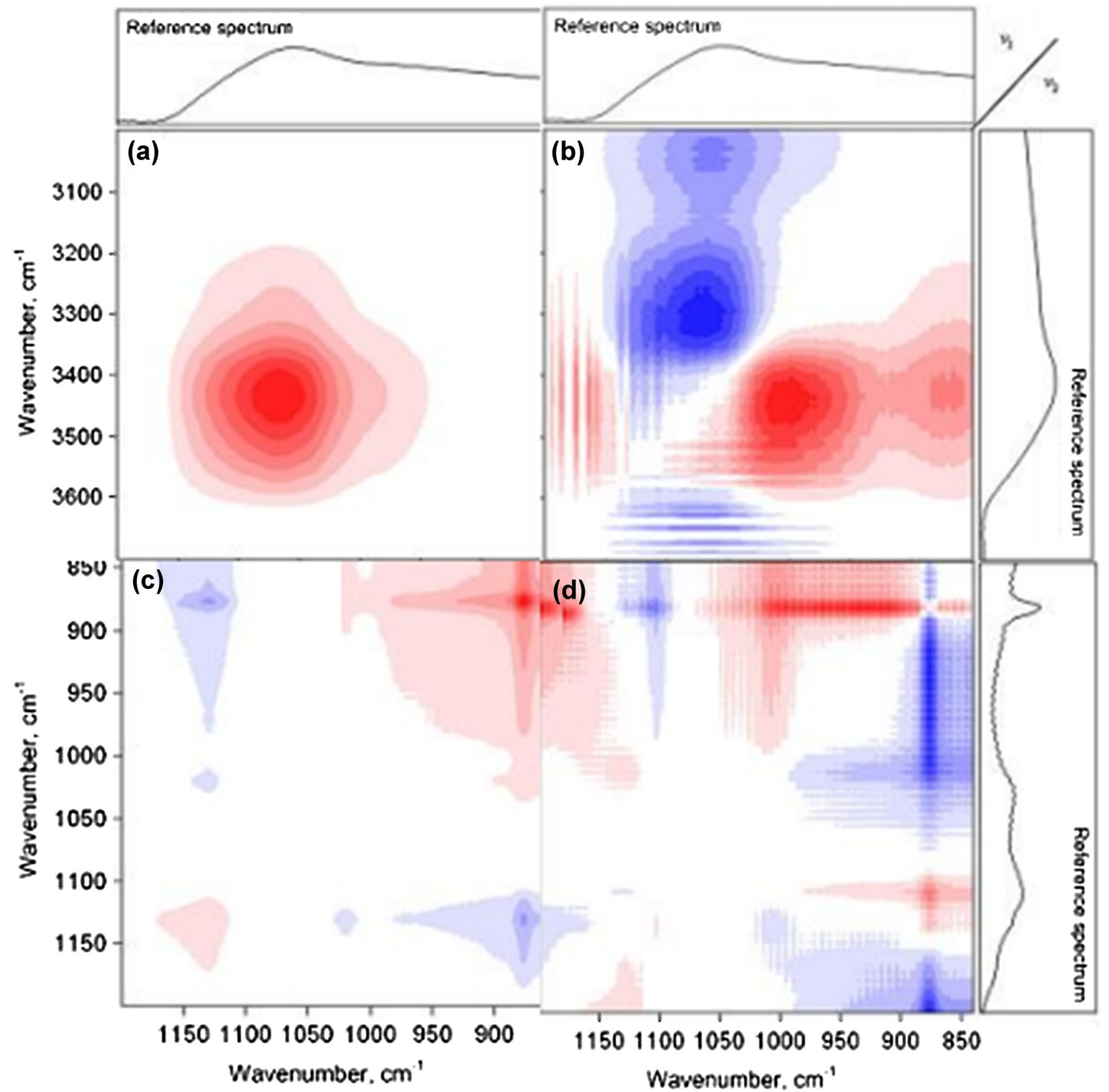

Fig. 6 2D FTIR illustrates the adsorption mechanism of Cs for synchronous (a) and asynchronous (b) scenarios at $1650-1200 \mathrm{~cm}^{-1}$. Besides, synchronous (c) and asynchronous (d) scenarios for $\mathrm{Cs}^{+}$at $1200-840 \mathrm{~cm}^{-1}$ are shown. The red and blue zones in the figure denote positive and negative correlations, respectively. At

the different coordination chemistry between two ions and adsorbents. This study provided much insight into the mechanism of ion exchange [3].

Theoretical computational chemistry was used to describe the metal binding preference with the sorbent. A comprehensive study was conducted about the preference of transition metals binding with calix[4]arene in the low rim. To reveal the stability of the binding system, binding

$1200-840 \mathrm{~cm}^{-1}$, the intensity of the peak at $1135 \mathrm{~cm}^{-1}$, which denotes the hydrogen bonding, decreased due to the increasing concentration of metal level (Modified from Al Lafi and Abdullah's study [3] (Copyright from Elsevier))

energy was calculated from the gas-phase energy system. Various software BLYP/6-311 $\mathrm{g} * *$, B3LYP/6-311 $\mathrm{g} * *$, and B3LYP/6-311 $\mathrm{g} * * / \mathrm{GD} 3 \mathrm{BJ}$ empirical dispersions were applied on the binding trend for the first row of transition metals, from which good linearity was shown and the gap increased between different models on the metal when the atomic number increased. Density functional theory (DFT) was involved as well, and two ions, $\mathrm{Mn}^{4+}$ (quartet) and 
$\mathrm{Cr}^{4+}$ (triplet), were found to have insufficient spin polarizations. The deficient $3 \mathrm{~d}$ orbital resulted from the polarization of oxygen in the aromatic ring. This study significantly advanced the understanding of the metal binding mechanism with sorbents such as calixarene [65].

Chalcogenide compounds played an imperative role in the soft heavy metal remediation in terms of ion exchange. One of metal sulfides $\mathrm{KMnS}$ was modified to $\mathrm{KMgS}$, for the ion exchange of $\mathrm{Sr}^{2+}, \mathrm{Cs}^{+}$, and $\mathrm{Ni}^{2+}$. Since $\mathrm{Mn}^{2+}$ is easily shifted to $\mathrm{Mn}^{3+}, \mathrm{Mn}^{2+}$ is replaced by non-toxic $\mathrm{Mg}^{2+}$ without the change of oxidation states. When $\mathrm{K}_{\mathrm{d}}$ was in the range of $10^{3} \sim 10^{5}$, the adsorbent with exceptional selectivity was conceived. $\mathrm{K}_{\mathrm{d}}$ for $\mathrm{Cs}^{+}$and $\mathrm{Sr}^{2+}$ was $7.1 \times 10^{3}$ and $2.1 \times 10^{4} \mathrm{~mL} / \mathrm{g}$, respectively. The remarkable result occurred for $\mathrm{Ni}^{2+}$ in $\mathrm{Na}^{+}>5 \mathrm{M}$ solution where the strong bond $\mathrm{Ni}-\mathrm{S}$ led to high $\mathrm{K}_{\mathrm{d}}\left(1.5 \times 10^{5} \mathrm{~mL} / \mathrm{g}\right)$ [63].

\section{Conclusion}

This review highlighted several typical nanomaterials: nanocarbon especially GO, mesoporous material, and magnetic materials. These materials have remarkable sorption capacity and selectivity of heavy metals and radionuclides, and stability. TEM, SEM, FTIR, XPS, XANES, EXAFS, and BET have been used to characterize the structure and surface chemistry of materials and reveal the unique sorption mechanisms. They have been continuously advanced.

These materials also exhibited tunable morphology (wire, sphere, films to lamella) and flexible dimensions from 1D to 3D with synthetic methods. Self-assembly and nanocasting were the two main synthetic methods. Not only the alteration of pore size, pore volume, or particle size, but also the alteration of the process was possible through the controlling strategies. Advanced instrumentation and theoretical computation methods were employed to exploit the mechanisms. The major mechanisms of adsorption include ion exchange and inner complexation.

Green chemistry has been introduced into the synthesis and application of these materials to clean up hazardous contaminated water. Since most of the syntheses of nanomaterial involve polymerization, non-toxic and non-carcinogenic reagents are preferred to be used. The technique of biofuels from wastes through bacteria was awarded by American Chemical Society (ACS) for Environmental Science and Technology Award (2015). In addition, most of these nanomaterials are costly to produce in the industrial scale. Therefore, the next-generation materials for cleaning up contaminated waters with heavy metals and radionuclides should be characterized by cost-effectiveness, high efficiency, high selectivity, and green chemistry.
Acknowledgments This study was supported by U.S. Nuclear Regulatory Commission (NRC-HQ-84-15-G-0042 and NRC-HQ-12-G-380038), U.S. Department of Commerce (NOAA) (NA11SEC4810001003499), and in part by National Science Foundation of China (Grant No. 41371484).

\section{References}

1. Adriano DC (2013) Trace elements in the terrestrial environment. Springer Science \& Business Media, New York

2. Åkesson A, Barregard L, Bergdahl IA et al (2014) Non-renal effects and the risk assessment of environmental cadmium exposure. Environ Heal Perspect 122:431-438

3. Al Lafi AG, Al Abdullah J (2015) Cesium and cobalt adsorption on synthetic nano manganese oxide: a two dimensional infra-red correlation spectroscopic investigation. J Mol Struct 1093:13-23. doi:10.1016/j.molstruc.2015.03.027

4. Ararem A, Bouras O, Arbaoui F (2011) Adsorption of caesium from aqueous solution on binary mixture of iron pillared layered montmorillonite and goethite. Chem Eng J 172:230-236. doi:10. 1016/j.cej.2011.05.095

5. Aroua MK, Yin CY, Lim FN et al (2009) Effect of impregnation of activated carbon with chelating polymer on adsorption kinetics of $\mathrm{Pb}^{2+}$. J Hazard Mater 166:1526-1529. doi:10.1016/j.jhazmat. 2008.11.033

6. Audi G, Bersillon O, Blachot J, Wapstra A (2003) The NUBASE evaluation of nuclear and decay properties. Nucl Phys A (Atomic Mass Data Center) 729:3-128. doi:10.1016/j.nuclphysa.2003.11. 001

7. Awual MR, Rahman IMM, Yaita T et al (2014) pH dependent $\mathrm{Cu}$ (II) and $\mathrm{Pd}(\mathrm{II})$ ions detection and removal from aqueous media by an efficient mesoporous adsorbent. Chem Eng J 236:100-109. doi:10.1016/j.cej.2013.09.083

8. Awual MR, Yaita T (2013) Rapid sensing and recovery of palladium(II) using $N, \quad N$-bis(salicylidene)1,2-bis(2-aminophenylthio)ethane modified sensor ensemble adsorbent. Sensors Actuators B Chem 183:332-341. doi:10.1016/j.snb.2013.04.009

9. Awual MR, Yaita T, El-Safty SA et al (2013) Investigation of palladium(II) detection and recovery using ligand modified conjugate adsorbent. Chem Eng J 222:172-179. doi:10.1016/j.cej. 2013.02.058

10. Awual MR, Yaita T, Shiwaku H, Suzuki S (2015) A sensitive ligand embedded nano-conjugate adsorbent for effective cobal$\mathrm{t}$ (II) ions capturing from contaminated water. Chem Eng J 276:1-10. doi:10.1016/j.cej.2015.04.058

11. Babel S (2003) Low-cost adsorbents for heavy metals uptake from contaminated water: a review. J Hazard Mater 97:219-243. doi:10.1016/S0304-3894(02)00263-7

12. Babel S, Kurniawan TA (2006) Various water techologies to remove arsenic and mercury from contaminated groundwater: an review. In: Ohgaki S, Fukushi K, Katayama H et al (eds) South Asia water environment. IWA, London

13. Bai ZQ, Li ZJ, Wang CZ et al (2014) Interactions between Th(IV) and graphene oxide: experimental and density functional theoretical investigations. RSC Adv 4:3340-3347. doi:10.1039/ c3ra45938a

14. Barlow DA, Baird JK, Su C-H (2004) Theory of the von Weimarn rules governing the average size of crystals precipitated from a supersaturated solution. J Cryst Growth 264:417-423. doi:10.1016/j.jcrysgro.2003.12.047

15. Basketter DA, Angelini G, Ingber A, Kern PS, Menné T (2003) Nickel, chromium and cobalt in consumer products: revisiting safe levels in the new millennium. Contact Dermat 49:1-7. doi:10.1111/j.0105-1873.2003.00149.x 
16. Bethencourt D (2016) Crowd calls for Mich. gov.'s arrest in protest at his home. In: USA Today. http://www.usatoday.com/ story/news/nation-now/2016/01/18/crowd-calls-mich-govs-arrestprotest-his-home/78987258/. Accessed 19 Jan 2016

17. Blakeslee S (1984) The Juarez accident. In: New York Times. http://www.nytimes.com/1984/05/01/science/nuclear-spill-at-jua rez-looms-as-one-of-worst.html

18. Buesseler K, Aoyama M, Fukasawa M (2011) Impacts of the Fukushima nuclear power plants on marine radioactivity. Environ Sci Technol 45:9931-9935

19. Chen M (2012) Russian journal of plant physiology. Russ J Plant Physiol 59:772-780

20. Cui C, Qian W, Yu Y et al (2014) Highly electroconductive mesoporous graphene nanofibers and their capacitance performance at 4 V. J Am Chem Soc 136:2256-2259

21. Daikopoulos C, Bourlinos AB, Georgiou Y et al (2014) A functionalized phosphonate-rich organosilica layered hybrid material (PSLM) fabricated through a mild process for heavy metal uptake. J Hazard Mater 270:118-126. doi:10.1016/j.jhazmat.2014.01.045

22. Delchet C, Tokarev A, Dumail X et al (2012) Extraction of radioactive cesium using innovative functionalized porous materials. RSC Adv 2:5707. doi:10.1039/c2ra00012a

23. Dinu MV, Dragan ES (2010) Evaluation of $\mathrm{Cu}^{2+}, \mathrm{Co}^{2+}$ and $\mathrm{Ni}^{2+}$ ions removal from aqueous solution using a novel chitosan/clinoptilolite composite: kinetics and isotherms. Chem Eng J 160:157-163. doi:10.1016/j.cej.2010.03.029

24. Dumat C, Quiquampoix H, Staunton S (2000) Adsorption of cesium by synthetic clay-organic matter complexes: effect of the nature of organic polymers. Environ Sci Technol 34:2985-2989. doi:10.1021/es990657o

25. Dyer A, Newton J, Pillinger M (2010) Synthesis and characterisation of mesoporous silica phases containing heteroatoms, and their cation exchange properties. Part 3. Measurement of distribution coefficients for uptake of 137-Cs, 89-Sr and 57-Co radioisotopes. Microporous Mesoporous Mater 130:56-62. doi:10.1016/j.micromeso.2009.10.013

26. Ebner AD, Ritter JA, Navratil JD (2001) Adsorption of cesium, strontium, and cobalt ions on magnetite and a magnetite-silica composite. Ind Eng Chem Res 40:1615-1623. doi:10.1021/ ie $000695 \mathrm{c}$

27. Egodawatte S, Datt A, Burns EA, Larsen SC (2015) Chemical insight into the adsorption of chromium(III) on iron oxide/mesoporous silica nanocomposites. Langmuir 31:7553-7562. doi:10.1021/acs.langmuir.5b01483

28. El-Kamash AM (2008) Evaluation of zeolite A for the sorptive removal of $\mathrm{Cs}^{+}$and $\mathrm{Sr}^{2+}$ ions from aqueous solutions using batch and fixed bed column operations. J Hazard Mater 151:432-445. doi:10.1016/j.jhazmat.2007.06.009

29. El-Nahhal IM, El-Ashgar NM (2007) A review on polysiloxaneimmobilized ligand systems: synthesis, characterization and applications. J Organomet Chem 692:2861-2886. doi:10.1016/j. jorganchem.2007.03.009

30. El-Nahhal IM, Zaggout FR, Nassar MA et al (2003) Synthesis, characterization and applications of immobilized iminodiacetic acid-modified silica. J Sol Gel Sci Technol 28:255-265. doi:10. 1023/A:1026093419515

31. EPA (2000) America's children and the environment-a first view of available measures. http://www.motherjones.com/docu ments/531159-americas-children-and-the-environment-epa\#docu ment/p42/a84512. Accessed 01 Dec 2000

32. Ezzeddine Z, Batonneau-Gener I, Pouilloux Y et al (2015) Divalent heavy metals adsorption onto different types of EDTAmodified mesoporous materials: effectiveness and complexation rate. Microporous Mesoporous Mater 212:125-136. doi:10.1016/ j.micromeso.2015.03.013
33. Fan Z, Liu Y, Yan J et al (2012) Template-directed synthesis of pillared-porous carbon nanosheet architectures: high-performance electrode materials for supercapacitors. Adv Energy Mater 2:419-424

34. Fang F, Kong L, Huang J et al (2014) Removal of cobalt ions from aqueous solution by an amination graphene oxide nanocomposite. J Hazard Mater 270:1-10. doi:10.1016/j.jhazmat. 2014.01.031

35. Fantz A, Sgueglia K (2016) Flint mayor says $\$ 55$ million needed to replace lead pipes. In: CNN. http://www.cnn.com/2016/02/09/ politics/flint-mayor-cost-replace-pipes/index.html. Accessed 9 Feb 2016

36. Foster JP, Weinhold F (1980) Natural hybrid orbitals. J Am Chem Soc 102:7211-7218. doi:10.1021/ja00544a007

37. Grigoropoulou G, Christoforidis KC, Louloudi M, Deligiannakis $\mathrm{Y}$ (2007) Structure-catalytic function relationship of $\mathrm{SiO}_{2}$-immobilized mononuclear cu complexes: an EPR study. Langmuir 23:10407-10418

38. Ghodbane I, Nouri L, Hamdaoui O, Chiha M (2008) Kinetic and equilibrium study for the sorption of cadmium(II) ions from aqueous phase by eucalyptus bark. J Hazard Mater 152:148-158. doi:10.1016/j.jhazmat.2007.06.079

39. Gogoi D, Shanmugamani AG, Rao SVS et al (2013) Studies on adsorptive removal of radioactive cobalt from alkaline waste generated in sodium cooled fast breeder reactors. J Radioanal Nucl Chem 295:1531-1535. doi:10.1007/s10967-012-2291-z

40. Groat CG (2004) US geological survey. http://citeseerx.ist.psu. edu/viewdoc/citations;jsessionid=E9BD1ADB0FD570916B1790 9B19D40D31?doi=10.1.1.167.1727

41. Ha C-S, Lee SH, Park SS (2015) Organic-inorganic hybrid mesoporous silica material modified by sulfonic acid group for selective adsorption of metal ions and method of manufacturing the same. Assignee: Pusan National University IndustryUniversity Cooperation Foundation (KR). US patent 8,969,241 B2

42. Han F (2007) Biogeochemistry of trace elements in arid environments, vol 13. Springer Science \& Business Media, New York

43. Han FX, Banin A, Su Y et al (2002) Industrial age anthropogenic inputs of heavy metals into the pedosphere. Naturwissenschaften 89:497-504. doi:10.1007/s00114-002-0373-4

44. Han FX, Su Y, Monts DL et al (2003) Assessment of global industrial-age anthropogenic arsenic contamination. Naturwissenschaften 90:395-401. doi:10.1007/s00114-003-0451-2

45. Harvey PJ, Handley H, Taylor M (2015) Identification of the sources of metal (lead) contamination in drinking waters in northeastern Tasmania using lead isotopic compositions. Environ Sci Pollut Res 22:12276-12288

46. Hirakawa B (2014) Epichlorohydrin, in encyclopedia of toxicology, 3rd edn. Academic Press, Oxford

47. Ho YS, Porter JS, McKay G (2002) Equilibrium isotherm studies for the sorption of divalent metal ions onto peat: copper, nickel and lead single component systems. Water Air Soil Pollut 141:1-33

48. Hu Y, Shenderova OA, Brenner DW (2007) Carbon nanostructures: morphologies and properties. J Comput Theor Nanosci 4:199-221

49. Hu R, Shao D, Wang X (2014) Graphene oxide/polypyrrole composites for highly selective enrichment of U(VI) from aqueous solutions. Polym Chem 5:6207-6215. doi:10.1039/ C4PY00743C

50. Jacqueline-Alonzo F, Parisot F, Plaire D, et al (2014) A mechanistic approach to link biological effects of radioactive substances from molecules to populations in wildlife species-a mechanistic approach to link biological effects of radionuclides from molecules to populations in wildlife species. In: International conference on radioecology and environmental radioactivity, Barcelona 
51. Johnston WR (1983) Ciudad Juarez orphaned source dispersal. Database radiological incidents related events. http://www.john stonsarchive.net/nuclear/radevents/1983MEX1.html. Accessed 23 Nov 2005

52. Kang S, Mauter MS, Elimelech M (2008) Physicochemical determinants of multiwalled carbon nanotube bacterial cytotoxicity. Environ Sci Technol 42:7528-7534. doi:10.1021/es8010173

53. Kanivets VV, Voitsekhovitch OV, Simov VG, Golubeva ZA (1999) The post-Chernobyl budget of ${ }^{137} \mathrm{Cs}$ and ${ }^{90} \mathrm{Sr}$ in the Black Sea. J Environ Radioact 43:121-135. doi:10.1016/S0265931X(98)00087-3

54. Kumari M, Pittman CU, Mohan D (2015) Heavy metals [chromium (VI) and lead (II)] removal from water using mesoporous magnetite $\left(\mathrm{Fe}_{3} \mathrm{O}_{4}\right)$ nanospheres. $\mathrm{J}$ Colloid Interface Sci 442:120-132. doi:10.1016/j.jcis.2014.09.012

55. Landis W, Sofield R, Yu M-H (2000) Introduction to environmental toxicology: molecular substructures to ecological landscapes. CRC Press, Boca Raton

56. Lazarus O (2016) In Flint, Michigan, a crisis over lead levels in tap water. In: PRI. http://www.pri.org/stories/2016-01-07/flintmichigan-crisis-over-lead-levels-tap-water. Accessed 7 Jan 2016

57. Li Y, Sheng G, Sheng J (2014) Magnetite decorated graphene oxide for the highly efficient immobilization of $\mathrm{Eu}(\mathrm{III})$ from aqueous solution. J Mol Liq 199:474-480. doi:10.1016/j.molliq. 2014.08.009

58. Li Z, Chen F, Yuan L et al (2012) Uranium(VI) adsorption on graphene oxide nanosheets from aqueous solutions. Chem Eng J 210:539-546. doi:10.1016/j.cej.2012.09.030

59. Liu M, Wen T, Wu X et al (2013) Synthesis of porous $\mathrm{Fe}_{3} \mathrm{O}_{4}$ hollow microspheres/graphene oxide composite for $\mathrm{Cr}(\mathrm{vi})$ removal. Dalt Trans 42:14710. doi:10.1039/c3dt50955a

60. Liu Y, Meng X, Luo M et al (2015) Synthesis of hydrophilic surface ion-imprinted polymer based on graphene oxide for removal of strontium from aqueous solution. J Mater Chem A 3:1287-1297

61. Manos M, Kanatzidis M (2012) Layered metal sulfides capture uranium from seawater. J Am Chem Soc 134:16441-16446

62. Mercier F, Alliot C, Bion L et al (2006) XPS study of Eu(III) coordination compounds: core levels binding energies in solid mixed-oxo-compounds EumXxOy. J Electron Spectrosc Relat Phenom 150:21-26. doi:10.1016/j.elspec.2005.08.003

63. Mertz JL, Fard ZH, Malliakas CD et al (2013) Selective removal of $\mathrm{Cs}^{+}, \mathrm{Sr}^{2+}$, and $\mathrm{Ni}^{2+}$ by $\mathrm{K} 2 \mathrm{xMgxSn} 3-\mathrm{xS} 6(\mathrm{x}=0.5-1)$ (KMS-2) relevant to nuclear waste remediation. Chem Mater 25:2116-2127. doi:10.1021/cm400699r

64. Morohashi T, Sano T, Yamada S (1994) Effects of strontium on calcium metabolism in rats. I. A distinction between the pharmacological and toxic doses. Jpn J Pharmacol 64:155-162. doi:10.1254/jjp.64.155

65. Murphy P, McKinlay RG, Dalgarno SJ, Paterson MJ (2015) Toward understanding of the lower rim binding preferences of Calix[4]arene. J Phys Chem A 119:5804-5815. doi:10.1021/acs. jpca.5b02624

66. Murugesan A, Ravikumar L, SathyaSelvaBala V et al (2011) Removal of $\mathrm{Pb}(\mathrm{II}), \mathrm{Cu}(\mathrm{II})$ and $\mathrm{Cd}(\mathrm{II})$ ions from aqueous solution using polyazomethineamides: equilibrium and kinetic approach. Desalination 271:199-208. doi:10.1016/j.desal.2010.12.029

67. Nieman (2005) Investigating Washington, D.C.'s water quality. In: NiemanReports. http://niemanreports.org/articles/investigat ing-washington-d-c-s-water-quality/. Accessed 15 Mar 2016

68. Norouzian R, Lakouraj MM (2015) Preparation and heavy metal ion adsorption behavior of novel supermagnetic nanocomposite based on thiacalix [4] arene and polyaniline: conductivity, isotherm and kinetic study. Synth Metals 203:135-148. doi:10.1016/ j.synthmet.2015.01.005
69. Olguin MT, Solache M, Iturbe JL et al (1996) Separation science and technology sorption of $\mathrm{Np}$ and fission products by Zeolite $\mathrm{Y}$, Mexican natural erionite, and bentonite. Sep Sci Technol 31:2021-2044

70. Pangeni B, Paudyal H, Inoue K et al (2014) Preparation of natural cation exchanger from persimmon waste and its application for the removal of cesium from water. Chem Eng J 242:109-116. doi:10.1016/j.cej.2013.12.042

71. Parsons-Moss T, Wang J, Jones S et al (2014) Sorption interactions of plutonium and europium with ordered mesoporous carbon. J Mater Chem A 2:11209. doi:10.1039/c4ta01740d

72. Pauling L (1960) The nature of the chemical bond and the structure of molecules and crystals: an introduction to modern structural chemistry. Cornell University Press, Ithaca

73. Qi G, Lei X, Li L et al (2015) Preparation and evaluation of a mesoporous calcium-silicate material (MCSM) from coal fly ash for removal of $\mathrm{Co}(\mathrm{II})$ from wastewater. Chem Eng $\mathrm{J}$ 279:777-787. doi:10.1016/j.cej.2015.05.077

74. Redman HC, McClellan RO, Jones RK et al (1972) Toxicity of $137-\mathrm{CsCl}$ in the Beagle. Early biological effects. Radiat Res 50:629-648

75. Sachse A, Merceille A, Barré Y et al (2012) Macroporous LTAmonoliths for in-flow removal of radioactive strontium from aqueous effluents: application to the case of Fukushima. Microporous Mesoporous Mater 164:251-258. doi:10.1016/j.micro meso.2012.07.019

76. Shin K-Y, Hong J-Y, Jang J (2011) Heavy metal ion adsorption behavior in nitrogen-doped magnetic carbon nanoparticles: isotherms and kinetic study. J Hazard Mater 190:36-44. doi:10. 1016/j.jhazmat.2010.12.102

77. Skoryna S, Fuskova M (1985) Handbook of stable strontium. Plenum, New York

78. Sun Y, Chen C, Tan X et al (2012) Enhanced adsorption of $\mathrm{Eu}(\mathrm{III})$ on mesoporous $\mathrm{Al}_{2} \mathrm{O}_{3}$ /expanded graphite composites investigated by macroscopic and microscopic techniques. Dalton Trans 41:13388-13394. doi:10.1039/c2dt31510f

79. Sun Y, Ding C, Cheng W, Wang X (2014) Simultaneous adsorption and reduction of $\mathrm{U}(\mathrm{VI})$ on reduced graphene oxidesupported nanoscale zerovalent iron. J Hazard Mater 280:399-408. doi:10.1016/j.jhazmat.2014.08.023

80. Sun Y, Shao D, Chen C et al (2013) Highly efficient enrichment of radionuclides on graphene oxide-supported polyaniline. Environ Sci Technol 47:9904-9910. doi:10.1021/es401174n

81. Sun Y, Yang S, Chen Y et al (2015) Adsorption and desorption of $\mathrm{U}(\mathrm{VI})$ on functionalized graphene oxides: a combined experimental and theoretical study. Environ Sci Technol 49:4255-4262. doi:10.1021/es505590j

82. Takagai Y, Furukawa M, Kameo Y, Suzuki K (2014) Sequential inductively coupled plasma quadrupole mass-spectrometric quantification of radioactive strontium-90 incorporating cascade separation steps for radioactive contamination rapid survey. Anal Methods 6:355-362. doi:10.1039/C3AY41067F

83. Tang L, Yang G-D, Zeng G-M et al (2014) Synergistic effect of iron doped ordered mesoporous carbon on adsorption-coupled reduction of hexavalent chromium and the relative mechanism study. Chem Eng J 239:114-122. doi:10.1016/j.cej.2013.10.104

84. Tselepidou A, Drosos M, Stathi P et al (2012) A water-dispersible, carboxylate-rich carbonaceous solid: synthesis, heavy metal uptake and EPR study. J Mater Sci 47:3140-3149

85. Valle-Vigón P, Sevilla M, Fuertes AB (2013) Carboxyl-functionalized mesoporous silica-carbon composites as highly efficient adsorbents in liquid phase. Microporous Mesoporous Mater 176:78-85. doi:10.1016/j.micromeso.2013.03.049

86. Wang S, Han C, Wang J et al (2014) Controlled synthesis of ordered mesoporous carbohydrate-derived carbons with flower- 
like structure and N-doping by self-transformation. Chem Mater 26:6872-6877. doi:10.1021/cm503669v

87. Wei Y, Zuo X, Li X et al (2014) Dry plasma synthesis of graphene oxide-Ag nanocomposites: a simple and green approach. Mater Res Bull 53:145-150. doi:10.1016/j.materresbull.2014.02. 015

88. Wen T, Wu X, Liu M et al (2014) Efficient capture of strontium from aqueous solutions using graphene oxide-hydroxyapatite nanocomposites. Dalton Trans 43:7464-7472. doi:10.1039/ c3dt53591f

89. Wu X-L, Wang L, Chen C-L et al (2011) Water-dispersible magnetite-graphene-LDH composites for efficient arsenate removal. J Mater Chem 21:17353. doi:10.1039/c1jm12678d

90. Yglesias M (2016) It's not just Flint—every major American city has hazardous amounts of lead hurting kids. In: Vox. http://www. vox.com/2016/1/19/10790534/lead-soil. Accessed 19 Jan 2016

91. Yu S, Wang X, Tan X, Wang X (2015) Sorption of radionuclides from aqueous systems onto graphene oxide-based materials: a review. Inorg Chem Front 2:593-612. doi:10.1039/C4QI00221K

92. Yu X-F, Liu Y-H, Zhou Z-W et al (2014) Adsorptive removal of $\mathrm{U}(\mathrm{VI})$ from aqueous solution by hydrothermal carbon spheres with phosphate group. J Radioanal Nucl Chem 300:1235-1244. doi:10.1007/s10967-014-3081-6
93. Zeiger E, Gollapudi B, Spencer P (2005) Genetic toxicity and carcinogenicity studies of glutaraldehyde - a review. Mutat Res 589:136-151. doi:10.1016/j.mrrev.2005.01.001

94. Zhang W, He X, Ye G et al (2014) Americium(III) capture using phosphonic acid-functionalized silicas with different mesoporous morphologies: adsorption behavior study and mechanism investigation by EXAFS/XPS. Environ Sci Technol 48:6874-6881. doi:10.1021/es500563q

95. Zhao D, Huo Q, Feng J et al (1998) Nonionic triblock and star diblock copolymer and oligomeric surfactant syntheses of highly ordered, hydrothermally stable, mesoporous silica structures. J Am Chem Soc 120:6024-6036. doi:10.1021/ja974025i

96. Zhao F, Repo E, Sillanpää M et al (2015) Green synthesis of magnetic EDTA- and/or DTPA-cross-linked Chitosan adsorbents for highly efficient removal of metals. Ind Eng Chem Res 54:1271-1281. doi:10.1021/ie503874x

97. Zhao F, Repo E, Yin D, Sillanpää MET (2013) Adsorption of $\mathrm{Cd}(\mathrm{II})$ and $\mathrm{Pb}(\mathrm{II})$ by a novel EGTA-modified chitosan material: kinetics and isotherms. J Colloid Interface Sci 409:174-182. doi:10.1016/j.jcis.2013.07.062

98. Zhu M, Diao G (2011) Synthesis of porous $\mathrm{Fe}_{3} \mathrm{O}_{4}$ nanospheres and its application for the catalytic degradation of xylenol orange. J Phys Chem C 115:18923-18934 